\title{
PEMBUATAN MIKROKOMPOSIT PURUN TIKUS (Eleocharis dulcis) DAN ECENG GONDOK (Eichornia crassipes) SEBAGAI FILLER DENGAN LIMBAH PLASTIK POLYETHYLENE TEREPHTHALATE (PET) SEBAGAI MATRIX
}

\author{
NINA HAIRIYAH ${ }^{*}$, R. RIZKI AMALIA ${ }^{1}$. APRILIA WIDYASTUTI ${ }^{1}$ \\ ${ }^{1}$ Jurusan Teknologi Industri Pertanian, Politeknik Negeri Tanah Laut, Jl. A.Yani, Km.6, \\ Desa Panggung, kec. Pelaihari, kab. Tanah Laut, Kalimantan Selatan 70815. Indonesia. \\ *Email: nina.hairiyah@gmail.com
}

\begin{abstract}
A composite is a material consisting of a mixture or combination of two or more materials either micro or macro, in which the material properties are of different shape and chemical composition of the original substance. The combination of two or more of the forming materials by mixing the non-homogeneous comprising matrix as a protector and filler as filler. Purun tikus and eceng gondok is one of the plants that contain cellulose. Pure cellulose material derived from purun tikus and eceng gondok can be an alternative filler material due to its strong fiber properties (high modulus) resulting in crystalline structure. The purpose of this research is to get filler formulation between natural fiber from purun tikus and eceng gondok using polyethylene terephthalate (PET) as matrix to produce microcomposite with best characteristic (texture, porosity and adhesion). The process of making microcomposite consists of 4 stages namely making purun tikus and eceng gondok then analyzed water content and density, fraction of cellulose, making matrix from PET waste and making microcomposite. The results showed that the best microcomposites were MKP1 with 30\% purun tikus filler and 70\% PET matrix and MKE 3 microcomposite with $50 \%$ eceng gondok filler and 50\% PET matrix.
\end{abstract}

Keywords: Microcomposite, Purun tikus, Eceng gondok, Cellulose

\begin{abstract}
ABSTRAK
Komposit adalah suatu material yang terdiri dari campuran atau kombinasi dua atau lebih material baik secara mikro atau makro, dimana sifat material yang tersebut berbeda bentuk dan komposisi kimia dari zat asalnya.Kombinasi antara dua atau lebih dari material pembentuk melalui pencampuran yang tidak homogen yang terdiri dari matrix sebagai pelindung dan filler sebagai pengisi. Purun tikus dan eceng gondok merupakan salah satutanaman yang memiliki kandungan selulosa. Bahan selulosa murni yang berasal dari purun tikus dan eceng gondok dapat menjadi bahan pengisi alternatif karena sifat seratnya yang kuat (modulus tinggi) sehingga menghasilkan struktur kristalin. Tujuan dari penelitian ini adalah untuk mendapatkan formulasi filler antara serat alam dari purun tikus dan eceng gondok dengan menggunakan polyethylene terephthalate (PET) sebagai matrix untuk menghasilkan mikrokomposit dengan karakteristik terbaik (tekstur, porositas dan daya rekat). Proses pembuatan mikrokomposit terdiri dari 4 tahap yaitu pembuatan serbuk purun tikus dan eceng gondok kemudian dianalisis kadar air dan densitas, fraksi selulosa, pembuatan matriks dari limbah PET serta pembuatan mikrokomposit. Hasil penelitian menunjukkan mikrokomposit terbaik adalah MKP1
\end{abstract}


dengan filler purun tikus 30\% serta matrix PET 70\% dan mikrokomposit MKE 3 dengan filler eceng gondok 50\% dan matriks PET 50\%.

Kata Kunci: Mikrokomposit, Purun Tikus, Eceng Gondok, Selulosa

\section{PENDAHULUAN}

Perkembangan teknologi dewasa ini yang menuntut dihasilkannya produk yang ramah lingkungan dan lebih ekonomis, membuat setiap industri berusaha memanfaatkan sumber daya alam yang dapat diperbaharui. Salah satunya industri komposit polimer yang saat ini semakin berkembang, terutama penggunaan seratserat alami sebagai bahan pengisi atau filler. Komposit terbentuk dari suatu proses pencampuran atau penggabungan dua atau lebih konstituen, yang berbeda dalam hal bentuk, sifat maupun komposisinya. Penggabungan bahan-bahan tersebut diharapkan dapat memberikan bentuk dan sifat yang lebih baik dari bahan semula (Hairiyah, 2016).

Perkembangan penelitian terdahulu di bidang komposit lebih difokuskan pada bahan-bahan yang mengandung selulosa sebagai pengisi. Berbagai jenis bahan pengisi yang telah digunakan dalam komposit dengan matrik polyprhophilen antara lain adalah tempurung kelapa (Hamid, 2008), kertas putih bekas (Tanjung, 2008), serat tandan kosong kelapa sawit (Nurjana, 2007), serat tongkol jagung (Hairiyah, 2016) dan serat daun nanas (Nasiah, 2016).

Penelitan tentang komposit berbasis serat sangat beragam.Mulai dari variasi jenis matrik dan serat, hingga bahan dasar matrik maupun serat. Penelitian juga berkembang dengan penggunaan bahan serat alam untuk beberapa variasi matrik sintetis dan alami. Komposit dengan penguat serat alam ini semakin intensif dikembangkan karena berkaitan dengan meluasnya penggunaan komposit pada berbagai bidang kehidupan serta tuntutan penggunaan material yang murah, ringan, sifat mekanik yang kuat dan tidak korosif sehingga dapat menjadi bahan alternatif selain logam.

Kabupaten Tanah Laut memiliki luas sekitar 363,135 ha dimana diantaranya adalah lahan rawa pasang surut seluas 16,496 ha (Dinas Pertanian, 2016). Salah 
satu tumbuhan rawa yang banyak tumbuh di lahan rawa Tanah Laut adalah purun tikus (Eleocharis dulcis) dan eceng gondok (Eichornia crassipes). Sampai saat ini pemanfaatan purun tikus oleh masyarakat setempat hanya sebatas untuk pembuatan karpet (tikar) sedangkan untuk eceng gondok masih kurang dimanfaatkan. Berdasarkan data, tanaman purun tikus mengandung 32,62\% (Sunardi, 2012) dan eceng gondok mengandung 60\% selulosa(Ahmad, 2012 dalam Putra, 2012) sehingga sebagai alternatif kedua tanaman rawa ini dapat dibuat menjadi produk komposit.

Bahan selulosa murni yang berasal dari purun tikus dan eceng gondok dapat menjadi bahan pengisi alternatif karena mengandung selulosa yang cukup tinggi. Penggunaan selulosa murni sebagai bahan pengisi merupakan salah satu cara modifikasi polimer sintetik untuk memperoleh komposit yang mempunyai sifat mekanik dan sifat fisik yang baik (Marpaung, 2011).

Bahan selulosa murni yang berasal dari purun tikus dan eceng gondok masih belum dimanfaatkan, sehingga pada penelitian ini akan dilakukan proses pembuatan mikrokomposit berbahan baku filler selulosa purun tikus (Eleocharis dulcis) dan eceng gondok (Eichornia crassipes) serta polyethylene terephthalate (PET) sebagai matrik, kemudian menentukan formula mikrokomposit dengan karakteristik terbaik secara kualitatif (tekstur, porositas dan daya rekat).

\section{METODE PENELITIAN}

\section{Bahan}

Bahan yang digunakan adalah purun tikus dan eceng gondok yang berasal dari rawa, limbah plastik polimer polypropylene terephthalate (PET) dan MAPP. $\mathrm{NaOH} 15 \%$ dan $\mathrm{NaOCl} 1 \%$.

\footnotetext{
Alat

Alat-alat yang digunakan pada penelitian adalah alat gelas beaker $100 \mathrm{ml}$, cawan petri, pisau, neraca analitik, pipet ukur, blender, alat pirolisis, porselin,
} 
desikator, gunting, saringan, hot plate serta alat cetak alumunium ukuran $5 \times 5 \times 1$ $\mathrm{cm}$.

\section{Prosedur Penelitian}

Perlakuan dalam penelitian adalah perbedaan komposisi matrik polimer polypropylene terephthalate (PET) dan filler purun tikus dan eceng gondok yang diberikan, dimana pada penelitian ini persentasi komposisi yang dilakukan mengacu pada penelitianyang dilakukan oleh Nasiah (2016). Pengamatan karakteristik yang dilakukan meliputi perubahan sampel yang terjadi selama proses pengolahan, pengujian kadar air, densitas pada serbuk dan penentuan mikrokomposit terbaik dari 3 komposisi bahan baku yang digunakan untuk membuat mikrokomposit.

Tabel 1. Komposisi Pembuatan Mikrokomposit.

\begin{tabular}{cccc}
\hline Sampel & Filler & \% Filler & $\begin{array}{c}\text { Komposit } \\
\text { \% Matrik (PET) }\end{array}$ \\
& Purun tikus & $30 \%$ & $70 \%$ \\
MKP 1 & Purun tikus & $40 \%$ & $60 \%$ \\
MKP 3 & Purun tikus & $50 \%$ & $50 \%$ \\
MKE 1 & Eceng gondok & $30 \%$ & $70 \%$ \\
MKE 2 & Eceng gondok & $40 \%$ & $60 \%$ \\
MKE 3 & Eceng gondok & $50 \%$ & $50 \%$ \\
\hline
\end{tabular}

1. Pembuatan serbuk purun tikus dan eceng gondok

Sebanyak $400 \mathrm{~g}$ purun tikus dan eceng gondok dicuci dan ditiriskan, kemudian dipotong-dipotong hingga halus, dikeringkan hingga kadar air kurang dari $10 \%$ dihancurkan menjadi serbuk dan disaring kemudian dilakukan uji analisis kadar air dan densitas. Adapun rumus perhitungan kadar air sebagai berikut: (Nasiah, 2016)

$$
\begin{aligned}
\text { Kadar Air } & =\frac{A-B}{C} \times 100 \% \\
\text { Keterangan: } \quad \mathrm{A} & =\text { Berat cawan kosong }+ \text { sampel kering }(\text { gram }) \\
\mathrm{B} & =\text { Berat cawan dengan sampel yang sudah dikeringkan } \\
\mathrm{C} & =\text { Berat sampel }
\end{aligned}
$$


Prinsip pelaksanaan analisis densitas adalah ditimbang sampel masingmasing $2 \mathrm{~g}$, dimasukan ke dalam gelas ukur $50 \mathrm{ml}$ dan isi air $30 \mathrm{ml}$, ditunggu selama 15 menit sampai sampel terendam kedalam air, diukur tinggi air yang naik keatas (Nasiah, 2016). Rumus perhitungan densitas terhadap serbuk:

$$
\rho=\frac{m}{v}
$$

$$
\begin{array}{ll}
\text { Keterangan: } & \rho=\text { massa jenis } \\
& m=\text { massa } \\
v & =\text { volume }
\end{array}
$$

\section{Pembuatan bubuk fraksi selulosa}

Serbuk purun tikus dan eceng gondok direndam dalam $\mathrm{NaOCl} 1 \%$ selama 5 jam dengan suhu $28^{\circ} \mathrm{C}$, kemudian dicuci hingga bersih dan disaring, serbuk daun purun tikus dan eceng gondok terdelignifikasi, setelah itu dilakukan pengeringan pada suhu $50^{\circ} \mathrm{C}$ selama 48 jam, kemudian direndam dalam larutan $\mathrm{NaOH} 15 \%$ selama 24 jam pada suhu $28^{\circ} \mathrm{C}$, disaring dan dicuci ampas purun tikus dan eceng gondok, dikeringkan lagi pada suhu $50^{\circ} \mathrm{C}$ selama 48 jam, didapat serbuk fraksi selulosa purun tikus dan eceng (Nasiah, 2016).

\section{Pembuatan matriks dari limbah plastik polyethylene terephthalate}

Sebanyak 500g limbah plastik PET yang didapatkan dari TPA Bakunci Pelaihari dicuci bersih, dipotong-potong dan dikeringkan, dipanaskan dengan menggunakan alat pirolisis selama 2 jam dengan suhu $300^{\circ} \mathrm{C}$ kemudian di blender dan disaring dengan saringan dilanjutkan dengan analisis densitas.

\section{Pencetakaan Mikrokomposit}

Pencetakan mikrokomposit dilakukan dengan penambahan matrik polimer PET kemudian dipanaskan hingga suhu $170^{\circ} \mathrm{C}$, ditambahkan perekat $2,5 \%$ yang telah dilarutkan dengan air sebanyak $10 \mathrm{ml}$, filler purun tikus dan eceng gondok dipanaskan hingga suhu $50^{\circ} \mathrm{C}$, pencampuran dan penggadukan hingga merata, pencetakan dalam casting ukuran 5 x 5 x $1 \mathrm{~cm}$ (Nasiah, 2016). 
5. Penentuan Mikrokomposit Terbaik

Mikrokomposit yang telah dikeluarkan dari casting, diamati karakteristik masing-masing sampel baik dari tekstur, porositas, dan daya rekat. Pengamatan dilakukan secara kualitatif (Widyastuti, 2017) dengan memberikan parameter penilaian :

1) Tekstur

$\begin{array}{ll}\text { Keras } & =(++) \\ \text { Cukup keras } & =(+-) \\ \text { Lembek } & =(-+) \\ \text { Sangat lembek } & =(--)\end{array}$

2) Porositas

Padat $\quad=(++)$

Cukup padat $\quad=(+-)$

Berongga $\quad=(-+)$

Sangat Berongga $\quad=(--)$

3) Daya rekat

$\begin{array}{ll}\text { Merekat } & =(++) \\ \text { Cukup merekat } & =(+-) \\ \text { Kurang merekat } & =(-+) \\ \text { Tidak merekat } & =(--)\end{array}$

HASIL DAN PEMBAHASAN

Rendemen

Rendemen merupakan suatu parameter yang paling penting untuk mengetahui seberapa besar produk yang akan dihasilkan, perhitungan rendemen berdasarkan. persentase perbandingan antara berat akhir dengan berat awal proses (Wahyunindiani, 2005 dalam Nasiah, 2016). Berdasarkan hasil penelitian yang telah dilakukan, rendemen selulosa untuk sampel purun tikus adalah sebesar $26,89 \%$, nilai ini lebih kecil dari hasil penelitian yang dilakukan oleh Sunardi (2012) yaitu sebesar 32,62\%. Nilai rendemen yang lebih kecil ini kemungkinan 
terjadi karena jenis sampel purun tikus yang digunakan berbeda, namun nilai rendemen selulosa 26,89\% ini cukup berpotensi untuk dimanfaatkan menjadi mikrokomposit.

Rendemen selulosa untuk sampel eceng gondok pada penelitian ini adalah sebesar 56,24\%, hal ini cukup mendekati hasil penelitian yang dilakukan oleh Ahmad (2012) yang menyimpulkan nilai rendemen selulosa eceng gondok adalah sebesar $60 \%$. Nilai selulosa yang lebih dari 50\% dari tanaman eceng gondok dirasa sangat berpotensi untuk dimanfaat menjadi mikrokomposit.

\section{Densitas}

Densitas merupakan salah satu parameter terpenting dalam mempelajari perubahan yang terjadi pada serbuk. Tujuan dilakukannya pengujian densitas terhadap serbuk adalah untuk mengetahui kepadatan pada sampel tersebut (Nasiah, 2016). Berdasarkan hasil perhitungan densitas air terhadap sampel, didapatkan hasil densitas untuk sampel purun tikus $0,28 \mathrm{~g} / \mathrm{cm}^{3}$, eceng gondok $1 \mathrm{~g} / \mathrm{cm}^{3}$, dan plastik PET $0,5 \mathrm{~g} / \mathrm{cm}^{3}$. Dari ketiga bahan yang dgunakan densitas yang paling tinggi terdapat pada serat purun tikus.

Berdasarkan penelitian yang telah dilakukan Soedojo tahun 2004 (dalam Nasiah, 2016) hal ini dikarenakan beberapa faktor yang telah dilakukan berat jenis suatu sampel seperti temperatur, dimana pada suhu yang tinggi sampel yang diukur berat jenisnya dapat menguap sehingga dapat mempengaruhi berat jenisnya, sedangkan pada suhu yang sangat rendah dapat menyebabkan sampel membeku sehingga sulit untuk menghitung berat jenisnya.

\section{Kadar Air}

Jumlah kandungan kadar air yang tinggi akan mempengaruhi bahan disebabkan oleh adanya mikroba maupun jamur. Kadar air merupakan karakteristik yang sangat mempengaruhi bahan seperti tekstur produk sehingga akan terjadi perubahan pada produk yang dihasilkan, selain kerusakan mikrobiologis, kadar air yang tinggi juga dapat mempengaruhi sifat-sifat fisik seperti kekerasan dan kekeringan. Berdasarkan hasil penelitian didapat bahwa kadar air pada sampel 
serbuk purun tikus sebesar 2,47\% dan eceng gondok 1,99\%. Nilai kadar air sampel yang digunakan sudah dibawah $10 \%$ sehingga layak untuk digunakan sebagai sampel.

\section{Fraksi Selulosa}

Selulosa adalah polimer glukosa rantai lurus yang berhubungan dengan rantai $\beta$ 1,4-glycosidic. Fraksi selulosa dapat di ubah menjadi glukosa dengan hidrolisis enzimatik, menggunakan selulase, atau cara kimia (Fachry, 2013). Dalam penelitian ini fraksi selulosa didapatkan dengan cara kimia menggunakan larutan $\mathrm{NaOCl}$ dan $\mathrm{NaOH}$. Perendaman dengan menggunakan $\mathrm{NaOCl}$ adalah $1 \%$ pada sampel serat purun tikus dan eceng gondok mengalami perubahan karakteristik, seperti warna dan tekstur. Fungsi dari $\mathrm{NaOCl} 1 \%$ pada proses perendaman adalah sebagai pemutih dan pengikat logam yang terdapat pada sampel (Fahmi 2011 Dalam Nasiah, 2016), sedangkan fungsi dari $\mathrm{NaOH}$ adalah untuk menghilangkan lignin, silica dan hemiselulosa dari serat agar memiliki impregnasi lebih baik antara serat dan matriks dan meningkatkan kekasaran permukaan serat (Leonard, 2013).

\section{Matrik Plastik polyethylene terephthalate (PET)}

Pada proses pembuatan matriks polimer polyethylene terephthalate (PET) dengan menggunakan alat pirolisis pada suhu $300^{\circ} \mathrm{C}$ selama 2 jam, terjadi perubahan karakteristik pada warna dan bentuk yang dapat dilihat pada Tabel 2.

Tabel 2. Perubahan Warna Dan Bentuk

\begin{tabular}{cccc}
\hline \multirow{2}{*}{ Sampel } & \multirow{2}{*}{ Pengamatan } & \multicolumn{2}{c}{ Perubahan } \\
\cline { 3 - 4 } & & Sebelum dipirolisis & Sesudah dipirolisis \\
\hline \multirow{2}{*}{ PET } & Bentuk & Lembaran & Serbuk \\
& Warna & Putih Bening & Hitam \\
\hline
\end{tabular}

Menurut (Billmeyer, 1971 dalam Spektrima, 2009) plastik PET memiliki film yang lunak, transparan dan flaksibel, mempunya kekuatan benturan serta kekuatan sobek yang baik, dengan pemanasan akan menjadi lunak dan mencair pada suhu $110^{\circ} \mathrm{C}$. 


\section{Mikrokomposit}

Berdasarkan hasil pembuatan mikrokomposit dengan penambahan MAPP sebanyak 2,5\% masing-masing perlakuan didapatkan hasil yang dapat dilihat pada Tabel 3.

\section{Tabel 3. Hasil Pengolahan Mikrokomposit}

\begin{tabular}{ll}
\hline Sampel & \multicolumn{1}{c}{ Keterangan } \\
\hline MKP 1 & $\begin{array}{l}\text { Matriks dan filler tercampur secara merata } \\
\text { dan teksturnya agak keras. }\end{array}$ \\
MKP 2 & $\begin{array}{l}\text { Matriks dan filler tercampur secara merata } \\
\text { dan teksturnya agak lembek }\end{array}$ \\
MKP 3 & $\begin{array}{l}\text { Matriks dan filler tidak tercampur secara } \\
\text { merata dan teksturnya lembek }\end{array}$ \\
MKE 1 & $\begin{array}{l}\text { Matriks dan filler tidak tercampur secara } \\
\text { merata dan teksturnya lembek. }\end{array}$ \\
dan teksturnya agak keras. & $\begin{array}{l}\text { Matriks dan filler tidak tercampur merata } \\
\text { dan tekstur agak lembek. }\end{array}$ \\
\hline
\end{tabular}


Penentuan Mikrokomposit Terbaik

Hasil penelitian untuk mendapatkan mikrokomposit terbaik secara kualitatif dapat dilihat pada Tabel 4.

Tabel 4. Hasil Penentuan Mikrokomposit Terbaik

\begin{tabular}{cccc}
\hline $\begin{array}{c}\text { Penilaian Mikrokomposit } \\
\text { terbaik }\end{array}$ & Tekstur & Porositas & Daya Rekat \\
\hline MKP 1 & +- & +- & +- \\
MKP 2 & +- & -+ & +- \\
MKP 3 & -- & -- & -- \\
MKE 1 & -- & -- & -- \\
MKE 2 & -+ & -+ & -+ \\
MKE 3 & ++ & ++ & ++ \\
\hline
\end{tabular}

\section{Keterangan:}

Tekstur $=$ Keras $(++)$

Porositas $=$ Padat $(++)$

Daya Rekat $=$ Merekat $(++)$

Cukup Keras (+ -)

Lembek (- +)

Cukup Padat (+ -)

Sangat Lembek (- -)

Berongga (- +)

Sangat Berongga (- -)

Cukup Merekat (+ -)

Kurang Merekat (- +)

Tidak Merekat (- -)

Berdasarkan hasil penelitian, mikrokomposit terbaik adalah sampel MKP 1 (filler 30\% dan matriks 70\%) yang memiliki tekstur (+), porositas (+) dan daya rekat (+) dibandingkan dengan perbandingan lainya seperti MKP 2 (40\% purun tikus : 60\% plastik polyethylene) dan MKP 3 (50\% purun tikus : 50\% plastik polyethylene), sehingga dengan formulasi filler dan matriks berbeda, maka dalam pembuatan mikrokomposit terbaik dengan serat alam purun tikus yaitu dengan formulasi 30\% filler dan 70\% matriks. Menurut ishaq (2011) Purun tikus dapat di jadikan sebagai komposit dengan hasil pengujian nilai sifat fisik yaitu kadar air $12,75 \%$ dan kerapatan $0,84 \mathrm{~g} / \mathrm{cm}^{3}$. Hasil pengujian sifat mekanik yaitu modulus elastisitas $10,750 \mathrm{Kg} / \mathrm{cm}^{2}$ dan modulus patah rata rata $80,5 \mathrm{Kg} / \mathrm{cm}^{2}$.

Hasil dari serat eceng gondok adalah MKE 3 (50\% eceng gondok :50\% plastik polyethylene) memiliki tekstur (+), porositas (+) dan daya rekat (+) dibandingkan dengan perbandingan lainya seperti sampel MKE 1(filler 30\% dan matriks 70\%) dan MKE 2 (40\% purun tikus : $60 \%$ plastik polyethylene. Menurut Bagir (2008) pembuatan komposit dari serat eceng gondok dengan menggunakan matriks unsaturade polyester resin tipe 157 BQTN dengan hardener MEKPO, dengan variasi berat serat 10,15, 20\%, variabel optimun diperoleh pada komposit dengan $20 \%$ berat serat, dengan kuat tarik $19 \mathrm{~N} / \mathrm{mm}^{2}$, kuat tekanan 18,44 N/mm². 


\section{KESIMPULAN}

Berdasarkan hasil penelitian yang dilakukan mikrokomposit terbaik didapatkan dengan penggunakan filler dari eceng gondok 50\% dan matrik PET 50 $\%$ dan filler dari purun tikus 30\% PET 70\%, sedangkan karakteristik mikrokomposit terbaik dari serat alam purun tikus memiliki tekstur (+ -) cukup keras, porositas (+ -) cukup padat dan daya rekat (+-) cukup merekat dan dari serat alam eceng gondok memiliki tekstur $(++)$ keras, porositas $(++)$ padat dan daya rekat $(++)$ merekat.

\section{DAFTAR PUSTAKA}

Bagir, Achmad dan Pradana, Eka. (2008). 'Pembuatan Serat Alam Eceng Gondok Sebagai Bahan Baku Pembuatan Komposit'. Jurusan Teknik Kimia, Universitas Diponegoro.

Billmeyer, W.F. (1994). 'Textbook of Polymer Science, $3^{\text {rd }}$. Jhon Wiley \& Sons.

Dinas Pertanian (2016). 'Laporan Penggunaan Lahan Kabupaten Tanah Laut'. Badan Pusat Statistik Tanah Laut.

Fachry, Rasyidi Ahmad. (2012). Pembuatan Bietanol Dari Limbah Tongkol Jagung Dengan Variasi Konsentrasi Asam Klorida Dan Waktu Fermentasi Jurnal Teknik Kimia No. 1, Vol.19.

Hairiyah, Nina.(2017). 'Karakteristik mekanik mikrokomposit dari tongkol jagung dan limbah plastik polipropilene'. Jurnal Teknologi Agro-Industri Volume 4 Nomor 1.

Hamid, Z.F.T. (2008). Pengaruh Modifikasi Kimia Terhadap Sifat-Sifat Komposit Polietilena Densitas Rendah (LDPE) Terisi Tempurung Kelapa, Tesis Sekolah Pasca Sarjana Universitas Sumatera Utara, Medan.

Ishaq, Dkk. (2011). Pembuatan Partikel Board Dengan Substitusi Bahan Matrik Komposit Tumbuhan Purun Tikus (Eleocharis Dulcis) Jurnal Prestasi. Volume 1. Nomor 1. Program Studi Fisika FMPIPA Unlam.

Leonard, Johannes.(2013). 'Pengaruh Penggunaan Larutan Alkali Dalam Uji Fourier Transform Infrared Pada Komposit Termoplastik Berpengisi Serbuk Serabut Kelapa'. Jurnal Teknik Kimia USU, Vol. 2, No. 2. Departemen Teknik Kimia, Fakultas Teknik, Universitas Sumatera Utara. 
Marpaung, Nalom D. (2011). 'Pemanfaatan Selulosa Dari Tandan Kosong Kelapa Sawit Sebagai Bahan Pengisi Komposit Polietilena Densitas Rendah (Ldpe)'. Tesis. Fakultas Teknik Universitas Sumatera Utara Medan.

Nasiah, Mahmudatul S. (2016). 'Pembuatan Mikrokomposit Dari Limbah Plastik PP Polypropylene Dengan Serat Alam Daun Nanas Dan Tongkol Jagung'. Tugas Akhir. Politeknik Negeri Tanah Laut.

Putera, Harya D.R. (2012). 'Ekstraksi serat selulosa dari tanaman eceng gondok (Eichhornia crassipes) dengan variasi pelarut'. Skripsi. Fakultas Teknik. UI

Spektrima, Tarra. (2009). 'Pembuatan Limbah Plastik Polietilene Tereftalat (PET) Sebagai Matrik Komposit Dengan Bahan Penguat Kaca'. Depertemen Kimia Fakultas Matematika Dan Ilmu Pengetahuan Alam Universitas Sumatra Utara Medan.

Sunardi dan Istikowati, W.T. (2012). 'Analisis Kandungan Kimia Dan Sifat Serat Tanaman Purun Tikus (Eleocharis Dulcis) Asal Kalimantan Selatan'. Jurnal Bioscientiae Volume 9, Nomor 2, Halaman 15-25.

Tanjung, A., Fadillah. (2008). 'Potensi Kertas Putih Bekas Sebagai Pengisi di Dalam Komposit Polietilena Densitas Rendah (LDPE).’ Tesis Sekolah Pasca Sarjana Universitas Sumatera Utara, Medan. 